\title{
How DO YOU SPELL “FREEDOM"? NARRATIVES ABOUT THE 25 April 1974 Revolution in THE Brazilian PRESS
}

\author{
Camila Garcia Kieling
}

\begin{abstract}
This paper proposes a recomposition of the intrigue of journalistic narratives on the Revolution of April 25, 1974 in Portugal based on the coverage of two Brazilian newspapers: O Estado de S. Paulo and Jornal do Brasil. The journalistic narrative is understood as a time orderer in the contemporaneity, expressing a "generalized circulation of historical perception" (Nora, 1979, p. 180), mobilized by the emergence of a new phenomenon: the event. The unusual coup d'état in Portugal stirred the world's political imagination, reviving confrontations between left and right. At that moment, in Brazil, the military dictatorship completed 10 years and the fourth president of the Armed Forces was beginning its mandate. Narratives are analyzed from different points of view: the organization of facts in time, the construction of characters, projections for the future, or the re-signification of the past.
\end{abstract}

\section{COMO SE ESCREVE “LIBERDADE"? NARRATIVAS SOBRE A REVOLUÇÃo DE 25 DE ABRIL DE 1974 NA IMPRENSA BRASILEIRA}

\begin{abstract}
RESUMO
Este artigo propõe uma recomposição da intriga de narrativas sobre a Revolução de 25 de Abril de 1974 em Portugal a partir da cobertura de dois jornais brasileiros de referência: o paulistano O Estado de S. Paulo e o carioca Jornal do Brasil. Compreendemos a narrativa jornalística como uma ordenadora do tempo na contemporaneidade, exprimindo uma "circulação generalizada da percepção histórica" (Nora, 1979, p. 180), mobilizada pela emergência de um novo fenômeno: o acontecimento. O incomum golpe de Estado em Portugal mexeu com o imaginário político mundial, reavivando confrontos entre esquerda e direita. Nesse momento, no Brasil, a ditadura militar completava 10 anos e iniciava-se o mandato do quarto presidente integrante das Forças Armadas. As narrativas são analisadas sob diferentes pontos de vista: por meio da organização dos fatos no tempo, da construção das personagens, das projeções para o futuro ou, ainda, da ressignificação do passado.
\end{abstract}




\section{INTRODUCtIon: 25 April 1974 ReVolution AND the BraZilian CONTEXT}

Revolução dos Cravos [Carnation Revolution] (April 25, 1974) and its resulting Revolutionary Process (PREC) stirred the mood of the press worldwide: "Portugal was regarded as the arena of a definite confrontation between left and right and this was one of the reasons it has fascinated so much the world's public opinion" (Vieira \& Monico, 2014, p. 337). The unusual coup d'état perpetrated by the military staff, between twists and turns, have effectively led to a democratic process watched closely by an incredulous and hopeful audience worldwide.

Before the Revolution, Portugal was ruled by a closed regime', known as Estado Novo [New State] or Salazarism (1933-1974), referring to its main leader, António de Oliveira Salazar (1889-1970). The Portuguese Estado Novo was more than a strong and repressive State. The regime was also sustained by a powerful imaginary, spread throughout everyday life, from politics and economics to education and amusements. Martins (1992, p. 194) studied school textbooks during the period, understanding these texts as "a cultural system, a system of interacting symbols, which is to say, as a network or a web of meanings that intersects" and integrates a "symbolic body, which acts on and reflects real life at the same time". The author exposes Salazarist's imaginary in its symbolism saudade and sebastianismo, past and future - that projects the image of an old, traditional and humble country, but with aspirations of a great empire: "On the one hand, the desired medievalism, bucolic and cordate, figured by the theme 'good housewife'. On the other hand, the ambition of being an Empire, daring and epic, figured by the caravels" (Martins, 1992, p 198).

Revolução dos Cravos, conducted by the Armed Forces Movement (MFA), was a movement that ended the dictatorship and started a process which led to a democratic regime, marked by the Constitution of April 25, 1976.

In Brazil in 1974, the dictatorship originated by the civil-military coup d'état against president João Goulart was completing 10 years and the fourth military president was taking office. The opposition celebrated the success of the Portuguese insurrection. Curiously, the Brazilian government, which have promoted friendly relations with right-wing dictatorial governments - such as those of Pinochet in Chile and Stroessner in Paraguay - promptly recognized the National Salvation Junta (JSN) settled in the Portuguese government, at the same time that offered political asylum to Américo Tomas, the deposed President of the Republic, and to Marcelo Caetano, Salazar's successor and president of the Council of Ministers. The unusual positioning was related to colonial matters, especially to the wars of independence of Angola, Mozambique and Guinea, since Brazil was interested in inheriting Portugal cultural and commercial influence over the colonies (Martinho, 2007).

\footnotetext{
' The dictatorship lasted for 48 years, from 1926 a 1974, divided in: Military Dictatorship (1926 to 1933), the Salazarist Estado Novo (1926 to 1968) and the Marcelist Estado Novo (1968 to 1974). In the last one, Marcelo Caetano took over the presidency of the Council of Ministers after the withdrawal of António Salazar, due to health issues (Rosas, 2013). About the nationalist and clerical nature of the Estado Novo, its authoritarian and undemocratic form and its corporate legitimacy, see Martins (2017). And on the Salazarist imaginary, see, also, Martins (2014).
} 
The mobilization of the public opinion about this institutional rupture event was followed up by newspapers, magazines, radio and television (the latter had an unprecedented role in the $20^{\text {th }}$ century revolutions) and is related to what Nora $(1979 ; 1983)$, in discussing the specificity of the so-called contemporary history, sees as a vast phenomenon of history democratization, derived from all that is usually understood as "globalization" - world wars, rapid communications, global-scale penetration of economies. It is a "generalized circulation of historical perception" that culminates in a new phenomenon: "the event" (Nora, 1979, p. 180). According to the author, mass communication plays a central role in this process: "Mass media has now the monopoly on history. In contemporary societies, it is through the media, and only through it, that an event reaches us and from which we cannot escape" (Nora, 1983, p. 5). More than simply means of transmitting messages, mass media embraces the very condition of the events existence.

Mediated and hopelessly covered by the currentness layer, the perception of change is impacted by this new way of knowing the world: the event. In this sense, the processes of economic, political and cultural changes have been reconfigured along the $20^{\text {th }}$ and the 21 st century - by the action of mass media, in a process that can be explained, at least in part, by the mythology of journalistic practice. Journalism is grounded on a paradox, since it uses mythological resources such as the one of the "construction of a narrative about itself as a mythical entity that manages the truth of social facts, and more, the enchanting rhetoric in the fragmented narration of the current happenings" (Sodré, 2009, p. 12). The liberalism mythology veils the disputes over the attribution of meanings that permeates the constitution of the journalistic discourse at the same time that it gives the news the status of neutral enlightenment.

It is mostly from the $20^{\text {th }}$ century, through the agency of mass media that change - or the mediatic reading of it - emerges as a preponderant value in western historical consciousness. Nora (1979, p. 184) also indicates the imaginary dimension of the mediate events: "to the extent that the event actually became intimately connected with its expression, its intellectual significance, close to a first form of historical elaboration, it was emptied in favor of its emotional potentialities. Reality proposes, the imaginary disposes". Displaced from the "mirror" perspective, journalism is understood as a narrative and as a "technology of the imaginary" (Silva, 2006). This activity provokes, through its techniques, a specific type of knowledge of the world. As a technology of the imaginary, journalism inquires the facts by means of spectacularization: "the facts only exist as narratives, among them, the journalistic narrative" (Silva, 2006, p. 107).

In theoretic-methodological terms, the journalistic narrative is an everyday narrative, a time mediator of the actions, an organizer of the experience between the past, the present and the future: "journalism observes the world from a current point of view, anchors its stories in the present to report the past and to anticipate the future. It operates a mediation that is, at the same time, linguistic and temporal" (Motta, 2005, p. 9). In this sense, the text is a starting point, and the fact that it only produces meaning in the relationship with historical human actors and with the context cannot be disregarded.

In order to deal with the journalistic narratives of the Revolution of April 25, 1974, we got really interested in copies of Brazilian reference press, national newspapers of 
expressive circulation. We have also sought for the composition of a corpus formed by newspapers that represented ideological groups and different journalistic languages. Thus, the selection includes $O$ Estado de S. Paulo, a liberal, conservative and anti-labor movement morning newspaper tied to the coffee growers from São Paulo, and O Jornal do Brasil, a newspaper from Rio de Janeiro marked by the dialogue with the working classes, and pioneer in the modernization process of graphic and editorial language in the Brazilian journalism in the 1960 s. Both were in favor of the civil-military coup that in April 1964 ousted President João Goulart. Ten years later, the relation with the military evidenced some wear and tear, perceived in the nuances and ambiguities of the coverage of the Portuguese revolution.

The events of April 25, 1974 were accompanied with hope, skepticism and unbelief concurrently all over the world. At that point, it could be another military coup covering oppressive intentions with promises of freeing, but it could also be an invigorating breath of freedom and a serious warning to other dictatorships, both in Europe and South America - in countries like Spain, Greece, Chile and Brazil. Therefore, we see that April 25 has brought to light a series of power disputes and exposed the complexity of the political relations at the historical moment, reported and interpreted by the press of the time.

\section{Portugal and the Future, The Caldas uprising and the regime collapse}

Revolução dos Cravos (April 25, 1974) and the resulting Revolutionary Process (PREC) in course stirred the mood of the press worldwide. "Portugal was regarded as the arena of a definite confrontation between left and right and this was one of the reasons the turmoil so much fascinated the world's public opinion" (Vieira \& Monico, 2014, p. 337). The unusual coup d'état perpetrated by the military staff, between twists and turns, effectively led to a democratic process watched closely by an incredulous and hopeful audience worldwide.

By this time, the printed media in Brazil was under censorship. According to Fico (2012, p. 87), the censoring practice started in the beginning of the military regime, but after December 1968, with the edition of the Institutional Act number five, it was reinforced. From that point on, censorship was "systematized, became a routine and started to conform to instructions specifically issued by the upper ranks of power". The most severe form of censorship was the prior censorship, but the most common were certain bans transmitted to newsrooms by small notes or by phone (Fico, 2012).

The daily and morning newspaper, O Estado de S. Paulo, has actively contributed to the accomplishment of the civil-military coup of 1964 in Brazil. After the coup, the relationship between the newspaper and the military became increasingly tense, and reached its peak in December, 1968, after the edition of the Institutional Act number five, with the editorial "Institutions in shambles". The newspaper edition was apprehended and a previous censorship on the wording was instituted. It would be suspended only in January, 1975.

In Brazil, Ernesto Geisel took office on March 15, 1974, when, according to O Estado de S. Paulo, he "appeals for unity" (Geisel faz apelo pela unidade, 1974, p. 1), suggesting 
that the appeal to cohesion of the Armed Forces cohesion is embedded into national imagination. On that day's edition, the newspaper reverberates what it calls the resurgence of "the political-military crisis in Portugal" (Recrudesce em Portugal a crise político-militar, 1974, p. 1), reporting the siege of the Military Academy by the Republican Guard on account of a meeting of officials that was taking place there to "discuss national military issues", and consequent return of the state of alert in the barracks. The article echoes the tension among the Forças Armadas [Portuguese Armed Forces] and mentions Spínola and Costa Comes's dismissal which occurred on March 14, 1974 caused by the disagreement between the military and the government in conducting the war in Africa.

On page two, the column of the correspondent Santana Mota, contradicts the cover story, stating that "in Portugal, the situation is less confusing now". According to the columnist, the top military officials have expressed support to the government overseas policy. The text also examines in details Spínola's attitude and the impact of the book Portugal and the Future that had came out in February, 1974 and caused a great deal of interest, mainly abroad, for suggesting that the solution to the war in African territories would not be military but political. Mota says that Spínola is considered a loyal and disciplined military man and that the book was published with the concurrence of his superiors and the government. The event of his dismissal is also minimized and interpreted "as the wiser process of ending the speculations and grooming attempts about the general that would certainly arise from all unsatisfied civil and military, as long as he remained in such a prominent position" (Mota, 1974, p. 2). Next to the correspondent's issue there is a cartoon by Bigatti: in an exquisite office, there is a portrait of Marcelo Caetano and, inside the garbage basket, there is a copy of the book Portugal and the Future (Figure 1). The cartoon along with the reading seems to refer to the government's triumph over Spínola's criticism. Or, in a more independent interpretation, it may indicate that under Caetano's regime, Portugal and the future are left in the garbage bin.

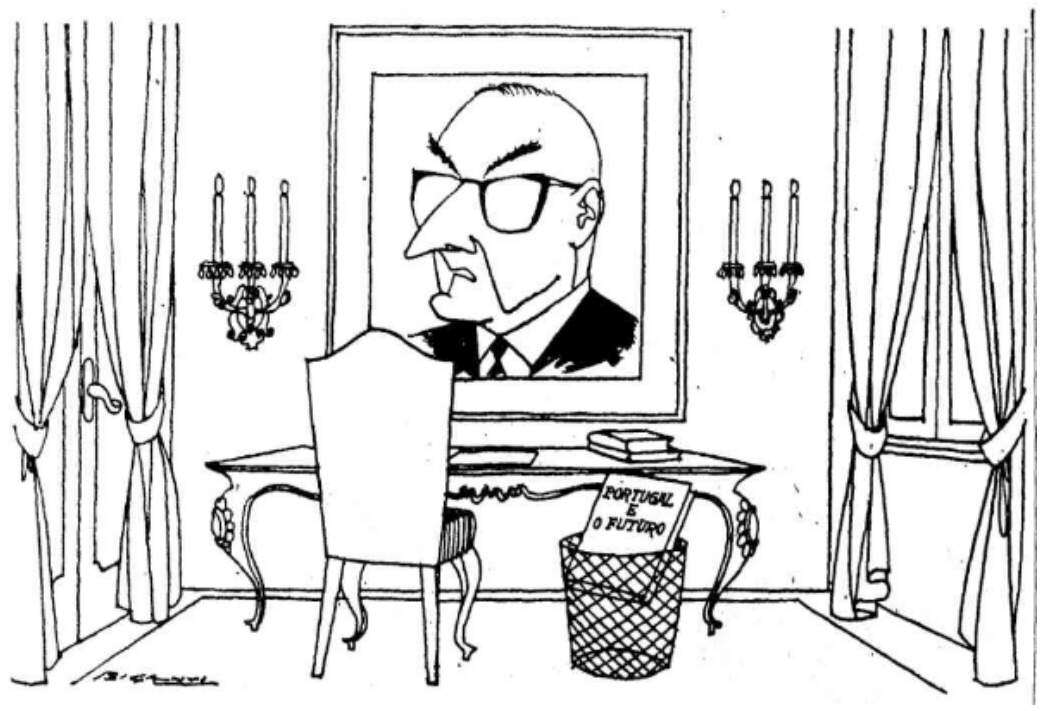

Figure 1: Portugal and the future left in the garbage bin

Source: O Estado de S. Paulo, March 16, 1974, p. 2) 
Portugal and the Future was published in Brazil by Nova Fonteira, owned by Carlos Lacerda, who also signed the edition forewords. O Estado de S. Paulo pages show an advertisement of the book (Figure 2) which says "the book that undermined a nation". Jornal do Brasil on April, 27 annouced that the book has sold out in Niteroi and Recife and also that within a short period more than 50 thousand copies have been sold in São Paulo (Livro se esgota em duas cidades, 1974, p. 9). Lacerda, the articulator of the coup of 1964 in Brazil and president João Goulart's fierce opponent, now lives in friction with the military, his political rights were suspended for 10 years in 1968 - and has engaged in journalism and business activities.

As an O Estado de S. Paulo associate, Lacerda signs a text in the edition of April 9 entitled "Portugal found the solution" where he classifies as "irrefutable" Spínola's analysis and proposal to solve the Portuguese situation, in which he emphasizes the dimension of Portugal democratization for solving the colonial problem. Lacerda further states that "there is an ongoing movement in Portugal" and the change is inevitable. Based on his own experience, he alerts "to the extent I can allege to be experienced in that matter I say that a delay in stating a solution will inevitably lead to an immediate take over by the Army" (Lacerda, 1974, p. 5).

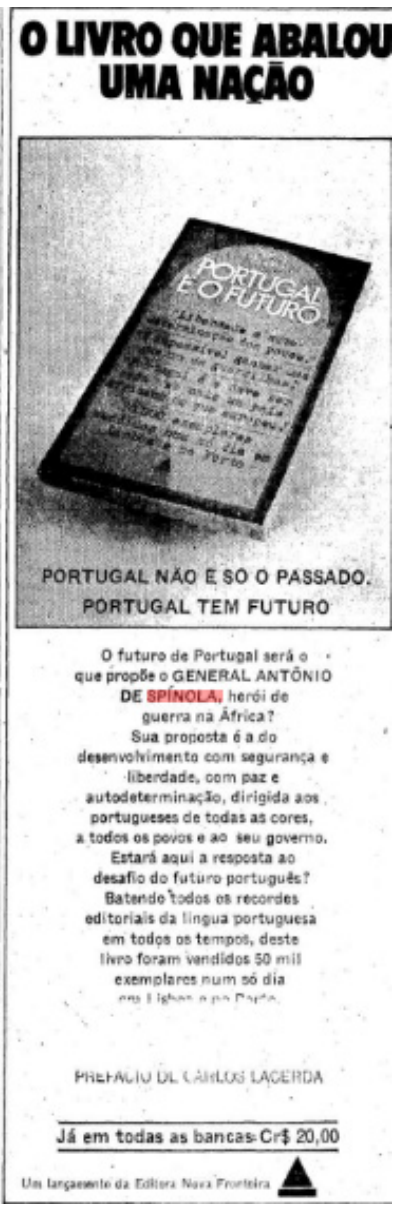

Figure 2: Advertisement of the book Portugal and the Future

Source: O Estado de S. Paulo, April 7, 1974, p. 26 
On March 17, O Estado de S. Paulo's frontpage main headline confirms the persisting crisis in Portugal. The march of the Fifth Infantry Regiment of Caldas da Rainha has been contained, but the increasing tension is characterized by $O$ Estado de S. Paulo through various aspects: the arrest of more than 100 officers, the reinstatement of a rigorous state of alert throughout the country, the distribution of leaflets on the streets of Lisbon criticizing the government's treatment of African territories in favor of political solutions for overseas issues and the blockage of Lisbon entries and exits, the custody of president Americo Tomás and the prime minister Marcelo Caetano. The article attributes the crisis to the publication of Spínola's book: "the whereabouts of General Spínola - author of the book Portugal e o Futuro, which publication has led to the current political-military crisis - is unknown and ignored even by his wife" (emphasis in original). Excerpts from the official statement of the Portuguese government are published describing the facts and stating that "order and calm reign throughout the country". Part of the information sources is not explicit, "rumors" and "observers" are cited to describe a critical moment: "according to observers, this is the most serious crisis that has ever occurred over the last 40 years in Portugal". For O Estado de S. Paulo, Caetano is still under pressure, on the one hand by those in favor of Spínola's thesis and, on the other hand, by the supporters of Américo Tomas's "hard line", "favoring the preservation of African territories by all means" (Lisboa sufoca revolta mas crise se agrava, 1974, p. 1) while opening up the possibility of space in the European Community.

The Portuguese government tries to show some control over the situation and that has also been reflected in the relations with Brazil. In addition, on the cover of March 17 edition, next to its main subject matter, there is a secondary article informing that the Portuguese chancellor Rui Patrício "strongly refuted the denomination Afro-Luso-Brazilian Community" to name the "system of economic relations between Brasília, Lisbon and the colonies in Africa. According to Patricio, the expression should be restricted to Luso-Brazilian Community" (Patrício rejeita alteração, 1974, p. 1). The chancellor, at the height of the Caldas uprising, was in Brasilia, where he was interviewed by the press.

Even so, tension increases, Spínola emerges as a leader, and the control of the Caldas da Rainha uprising is not recognized to be definitive victory. The O Estado de $S$. Paulo dedicates itself to drawing a profile of Spínola (text entitled "The deeds of Spínola highlights him as leader", Os feitos de Spínola o destacam como líder, 1974, p. 14), in which he is characterized as a military officer and a high-quality public administrator, evidences of which can be found especially in the period he was the governor and commander of Guinea, being respected and cherished by the soldiers.

On March 28, O Estado de S. Paulo publishes the news stating that "The insurgence in Portugal was part of a conspiracy". It also provides space to the Mozambican Liberation Front (Frelimo) to address the question of Spinolist solution for the Portuguese colonies in Africa. Frelimo rejected the proposal and claimed that Spínola was "a fascist philosopher" (Frelimo rejeita a proposta, 1974, p. 2). 


\section{The explosion of April 25}

In the Brazilian newspapers we analyzed the first reference to the military movement of the revolution in Portugal appears in Jornal do Brasil edition of April 25, 1974. On page 14, the news indicating the 2 nd cliché of the page in that edition, reports "Rebelious troop march toward Lisbon": "at today's dawn, troops of the 5th Regiment of Hunters occupied the Radio Clube of Portugal, and began to transmit bulletins in which the military 'asked all the Army and Police extreme caution to avoid any shock'" (Tropa rebelada marcha em direção à Lisboa, 1974, p. 14). The newspaper enterely transcribes the first communication of what it calls "a" Armed Forces Movement, a signed document that was circulating clandestinely "in which a reassessment of the policies followed by Portugal in its wars in Africa" was requested. On the third cliché of the April 25 issue, more details were published. The title turns into "Rebels try to avoid armed clashes in Lisbon" and refers to a "military uprising", according to the ANI (Information Agency), of proportions and nature yet unknown. We emphasize that Jornal do Brasil contacts the official agency of the Portuguese government (but also quotes AGP and UPI as sources) to confirm the existence of the movement which intentions are not clear yet, since in its transmissions "the Armed Forces Movement does not clarify what is intended, who leads, whether it is legalist or part of the movement against the government" (Rebeldes tentam evitar choque armado em Lisboa, 1974, p. 14).

On April 26, 1974, the whole cover of O Estado de S. Paulo is dedicated to Portugal. The paulistano newspaper opts for the headline: "Military coup overthrows the Portuguese government". In the lead, we can see that the State focuses the events on the highest officials. In addition to the military leadership, O Estado de S. Paulo points out the promises to restore democracy, convey a Constituent Assembly and general and free elections. The popular dimension appears on the cover, highlighted in secondary text entitled "The new regime is acclaimed on the streets of Lisbon". They are reports of daily life details, the festive atmosphere on the streets that demonstrate the popular enthusiasm with the events.

Two other titles use precision signals as a resource (in this case, the time) as a synthesis of texts: "Only 12 hours" and "At 4 pm, the end of an era". The first refers to the time elapsed between the first movements of tanks in Santarém, at four o'clock in the morning, and the entrance of Spínola in the Carmo Quarters at 6 pm, synthesizing and specifying a chronology of the facts. In "At 4 pm, the end of an era", correspondent Santana Mota highlights the protagonism of the young officers:

apparently, all the officers who participated in the coup consisted of young people, the majority with patents inferior to that of major. Speaking on the radio, these officials said they intended not only to abolish the regime, but also to hold free elections immediately, with full freedom of expression and assembly. (Mota, 1974, p. 1)

The last two cover texts, at the bottom of the page, deal with projections and developments, considered as relevant by the vehicle. In this case, O Estado de S. Paulo seeks to 
analyze the repercussions of the coup in Portugal, in Brazil and in the Portuguese colonies in Africa. "Itamaraty was not surprised", text signed by the Brasília branch, informs that since the publication of the book Portugal and the Future, Itamaraty understood that changes in Portuguese politics were inevitable, therefore it was not surprised, perhaps in an attempt to minimize the magnitude of the events and potential effects on the opposition to the military regime in Brazil. The text brings information about what a diplomat "has confided" to a journalist, stating that "Brazil finds itself in a delicate situation, because in its intention to be close to Arabs and Africans, Portugal represents an obstacle" (Itamaraty não foi surpreendido, 1974, p. 1). At the time, the authorities were still silent or evasive. From the African territories, no news so far, just silence.

In an editorial, O Estado de S. Paulo interprets the events in Portugal in the light of Geopolitcs, the Cold War and the Salazarism exhaustion in facing the country's problems. He compares the movement of April 25 with the beginning of the Portuguese dictatorship in 1926, stating that the same "armed classes (...) repeat the gesture of almost half a century ago and constitute a revolutionary junta, also entitled national salvation, on the debris of Marcelo Caetano's government" (A queda do regime português, 1974, p. 3). Adept of authoritarian solutions, the newspaper suggests a "process of re-education of the masses before the elections, so that they learn to make use of the heady freedom of thought, assembly, association, expression and vote" (A queda do regime português, 1974, p. 3).

The O Estado de S. Paulo coverage extends for another four whole pages in an attempt to contextualize the information for the Brazilian public, presenting the protagonists of the events in Portugal, the colonial issue and the repercussion in Brazil and worldwide. In relation to the main characters, O Estado de S. Paulo elects General Spínola, President Américo Tomas and Prime Minister Marcelo Caetano, as well as Salazar himself. O Estado de S. Paulo seeks to contextualize the facts didactically through maps and demographic information on the present "provinces" in Africa, the profile of the characters, data on the Armed Forces and bailout of historical texts on the Salazarism.

In relation to international repercussion, O Estado de S. Paulo elects London and Paris as viewpoints: Carlos Lacerda's opinion has nearly the same status as Nation, and he says that the character, now enemy of the Brazilian military, continues in the center of the media stage. Carlos Chagas, a journalist and former press officer of the Republic Presidency in 1969, under the administration of General Costa e Silva, also signs the column. Apart from the signed columns and individual opinions, the news text affirms that the "World awaits the outcome of the crisis" and gathers reactions generally characterized as of caution and apprehension, in London, in Madrid and in the Vatican. Several delegates of ONU, institution that a year before recognized the independence of Guinea, manifest satisfaction. In Rhodesia and South Africa, traditional supporters of overseas politics, "the Portuguese situation was accompanied yesterday with great interest" (Mundo aguarda o desfecho da crise, 1974, p. 9). Washington states that it has "no meaningful information" beyond the printed media (Mundo aguarda o desfecho da crise, 1974, p. 9). The TASS Soviet agency is the only one at this point to suggest a 
potential separation between the MFA and generals Francisco da Costa Gomes and Antonio de Spínola, who according to the source, have been invited by the leaders of the insurrection to join them. On the other hand, the analysis of the newspapers in study suggest that those generals were already the leaders of the Armed Forces movement and had not just joined on April 25.

From Paris, where he lived in exile, appears Mário Soares, from the Portuguese Socialist Party. Soares shows total confidence in the Army, differentiating it from the example of the Armed Forces of Chile that, in the previous year, deposed the socialist Salvador Allende and established a dictatorship led by General Augusto Pinochet. "We have no reason to doubt our Army's intention to bring down dictatorship" (Mário Soares oferece apoio, 1974, p. 9). The same article that talks about Soares, although the title does not say it ("Mário Soares offers support"), talks about the repercussions of the events among rebellion leaders in the African territories. From London, a note is sent by the Commission for the Liberation of Guinea and Mozambique. From Ottawa, Canada, Agostinho Neto, representative of the Movement for the Liberation of Angola (MPLA), affirms that the coup does not mean independence and that it would be necessary to wait to "verify the true motives for the coup" (Mário Soares oferece apoio, 1974, p. 9).

From London, the correspondent Hermano Alves reports that "the official and unofficial English midia" has received the news with undisguised sympathy and even enthusiasm" (Alves, 1974, p. 9). England's reaction is very relevant, since the AngloPortuguese Alliance is the oldest diplomatic alliance in the world (still in force) and also because that country, which have recently elected a Labor Prime Minister, have a strong commercial interest in the colonies as well as in what a coup derived from a potential "Composition with African nationalists" could mean for the South Africa apartheid and for the white supremacy of Rhodesia. According to the correspondent of $O$ Estado de $S$. Paulo, the British newspapers Guardian and The Times have recently reported the incursion of Rodesian troops in Mozambique.

Gilles Lapouge, correspondent in France, states that despite the lack of official reactions of the authorities and candidates (France was in full election campaign period), events in Portugal dominate the news reports in Paris. The journalist says he tried to talk "with several Portuguese workers in the worksites of Paris suburbs. Few wanted to make statements. Those who spoke said that they did not expect any major change in the situation of their country" (Lapouge, 1974, p. 9). The text also considers the popular dimension of the revolution, hitherto little explored by the journalistic narrative:

Either way, the news was greeted with joy by most of the French population. The presence of millions of Portuguese workers in this country could not fail to sensitize public opinion to the problem of people without rights, persecuted by a violent political police, led to poverty and disenchantment by an archaic regime. (Lapouge, 1974, p. 9)

In this sense, the article signed by the journalist Carlos Chagas states that "end of the regime only translates popular will" (emphasis added): 
it can be said, with little margin of error, that the present revolution had strictly popular bases, although conducted by the Portuguese military. It simply fell on them the task of waking up to reality and challenge it, for they had the means to do so. It lacked a unit or common denominator that came up with Antonio de Spínola's book in which he transposed to the paper not only the reaction of all, but pointed out a clear and precise solution to the stalemate. (Chagas, 1974, p. 9)

At the same time, the journalist attributes the events to the lack of competence and sensitivity of the Portuguese rulers - an interpretation that is recurrent in our analysis and affirms that "some revolutions are made for lack of bread, others for lack of order (...) It may be concluded that yesterday's movement was done for lack of intelligence" (Chagas, 1974, p. 9).

Carlos Lacerda's opinion complemented the page nine of O Estado de S. Paulo April 26 edition. The composition of the page gives the speech of the former governor in Guanabara the status of nation or authority. The other texts show a certain caution in those spheres, what can be translated into difficulty for journalists in obtaining official statements. Even with his political rights revoked, Lacerda does not present this problem, expressing his opinion freely, which demonstrates the relevance of this character in the Brazilian public scene. The title is "For Lacerda, what happened was predictable". In the article, "In sports clothes, very happy and receiving phone calls every moment", Lacerda imputed the predictability of the event to the publication of Spínola's book (the Brazilian version published by Nova Fronteira Publishing House, owned by the former governor). Known as "who overthrows presidents", the reporter asks if he had anyhow collaborated in the fall of the Portuguese dictatorship, a question to which he replied seriously: "Unfortunately, I did not have the honor of participating in anything" (Lacerda,1974, p. 9).

"It was a great day for the former governor, who started showing his emotion and hopes, that were likely the same as of all those who defend freedom for the peoples: "We are all to be congratulated', he repeated several times" (Para Lacerda, era previsível o que aconteceu, 1974, p. 9). Communism continues to be rejected in Lacerda's speech, and mentioned as a synonym of anarchy. He affirms that "what should be done there is to build a true democracy, dissociated from communism" (Para Lacerda, era previsível o que aconteceu, 1974, p. 9). Like Chagas, Lacerda attributes to the political incompetence of Marcelo Caetano the fact that the government did not perceive what was happening, especially among the Armed Forces.

Jornal do Brasil on April 26 opts for the headline "Junta controls Portugal and announces a Constituent". Through the narrative of the newspaper, the protagonist of the actions is the Junta de Salvação Nacional [National Salvation Junta], which had the "seal of approval of the Armed Forces Movement, denomination adopted by the rebels since the beginning of their action". In the spotlight are the immediate measures announced, such as the election of a Constituent Assembly by direct vote. On page 2, the headline "Military put an end to Salazarism and promise election" informs that the official 
announcement of the Junta happened immediately after the surrender of Caetano, but does not clarify its relationship with the MFA. The goals of the movement are also highlighted, General Spinosa himself disclosed them on a TV manifesto and through the "diplomatic observers in Lisbon", it emphasizes that "the new power holders, within the period of transition until the convocation for general elections, are assigned the task of eliminating from public life all the elements linked to Salazarism" (Militares acabam salazarismo e prometem eleição, 1974, p. 2), including the possibility of purging the Armed Forces.

In a chronology of the revolution ("How the rebel movement was"), Jornal do Brasil passes on the edition of the newspaper República, now censorship free and seen as 'liberal':

'the Armed Forces take over'. Under a red headline, the liberal newspaper República released yesterday an extensive report of the movement which culminated in the fall of Prime Minister Marcelo Caetano and announced to its readers that for the first time it has gone out to the streets without censorship. (Como foi o movimento rebelde, 1974, p. 2)

Jornal do Brasil narrative gives evidence of the confusion over the leadership of the movement. According to the chronology presented, in the end of the morning, with Lisbon taken by the MFA, especially in Carmelitas' Square, in front of the Carmo barrack, where Caetano was a refugee, there was yet an important piece of information missing for the press: "the names of the leaders of the movement were not yet known" (Como foi o movimento rebelde, 1974, p. 2).

The narrative of the Jornal do Brasil exalts the protagonism of Spínola: the surrender of Caetano had been rushed by his presence in the place. After the withdrawal of the arrested premier, "General Spínola's car left. He was wearing his uniform with all the decorations and was hailed by the crowd shouting "Hurrah for Spínola. Down with Fascism. Hurrah for Portugal" (Como foi o movimento rebelde, 1974, p. 2).

In his column, the journalist Carlos Castello Branco - says that Spínola lies in between the weight of the war and the spirit of the new generations, that is:

the inspiration of a general endowed with political vision and civic courage, who, after ruling Guinea and commanding the repressive forces, proposed in a book of great repercussion the end of the internal dictatorship in Portugal as a precondition for the survival of his homeland and the continuity of Portugal's influence on the Portuguese world. (Castello Branco, 1974, p. 4)

Marcelo Caetano, whom he refers to as a professor, is also found guilty by Castello for the Portuguese government being so unable to overcome the conservatism of the society inherited from Salazar and for keeping the country immersed in isolationism. Castello seeks to explore the role of Brazil face "our overseas frontier's" new situation. According to Castello, Brazil should be interested in the Portuguese world and not exclusively in Portugal, "to whose policy we lend the persistent sacrifice of our prestige in 
international organizations". He also sees Brazil as having a central role in preserving "a multinational system" (Castello Branco, 1974, p. 4).

On the news service, no official position of the Brazilian government is divulgated. The government awaits the manifestation of "a new government that takes form and exercises, in fact, its political authority over Portugal" (Brasil aguarda em silêncio, 1974, p. 4). However, on the short news items in the section "Informe Jornal do Brasil" we read the sentence: "Portugal: Brazil will immediately recognize the new Portuguese Government" (Informe Jornal do Brasil, 1974, p. 10). Jornal do Brasil also makes room for Carlos Lacerda's opinion, in the matter "Lacerda says that Spínola will democratize Portugal".

In an editorial, Jornal do Brasil dedicates itself to analyzing Brazil's role in the new Portuguese political configuration. It reinforces the thesis that changes in that country were predictable and reflected the popular will.

The predictable military and political movement that closed the government of Prime Minister Marcelo Caetano in Portugal was in fact the recognition that Portuguese public opinion demanded new paths for the country, which have been exhausted for 13 years in an inglorious war in their colonies in Africa. The movement was swift and virtually bloodless, which is the hallmark of actions that arise already supported by popular consensus. (BrasilPortugal, 1974, p. 6)

As public authority, Jornal do Brasil demands attitudes of the rulers, suggesting the immediate recognition of the new government: "immediately recognizing the Government that assumed power, Brazil should put itself in the service of Portuguese language community, in the old metropolis and in the former colonies". According to the newspaper, Brasília was already "away enough" from the Portuguese government and, it is imperative not to delay the meeting of the three worlds of Portuguese culture: the Lusitanian, the African, the Brazilian" (Brasil-Portugal, 1974, p. 6). Signed by the seal "Jornal do Brasil Research", "Portugal on the margins of the world" is a retrieval of the recent turbulent trajectory of this country in relation to international organizations such as ONU, Unesco, International Labor Organization and even differences with the Church, hoarding several signs it was in fact "on the margins of the world" (Portugal à margem do mundo, 1974, p. 4).

The popular dimension in Jornal do Brasil's narrative is in "People take to the streets of the Capital celebrating". The same stories reported on O Estado de S. Paulo, the same quotes, probably by the common origin - the AFP agency. Practically identical are also the stories about the return, hitherto possible, of Mário Soares to Portugal.

On April 27, Jornal do Brasil dedicated the photo and the headline of its main cover to Portugal: "Portugal announces civilian government and election in a year's time". Besides the highlights indicated in the title, which are the first measures announced by the Junta de Salvação Nacional, the release of political prisoners from Caxias prison and some international repercussions are also pointed out: the intention of Spain's immediate recognition of the new government, the Americans caution and the "European press" applaud to the end of Salazarism. 
The press coverage is divided into two, the events in Lisbon and the worldwide repercussion. In the first approach, we have "Junta dissolves Salazarist police and party". Among the first measures of the new government is the destruction of past Salazarist institutions: "less than a day after the victory of the armed movement, Salazarism began to disappear from Portuguese life. The work of reconstruction, according to Spínola, begins with the destruction of what "no longer serves us'" (Junta dissolve polícia e Partido salazaristas, 1974, p. 8).

One of the most prominent episodes is the question of the political prisoners in the Caxias prison in Lisbon. On one side, in the words of the Junta, the release of "all political prisoners not committed to other types of crimes" (Spínola solta presos políticos, 1974, p. 8), including military prisoners in the Caldas Uprising; on the other, the arrest, in the same center, of the political police officers who resisted at the headquarters of the DGS (General Department of Security, the old PIDE). According to Jornal do Brasil, a crowd of 2,000 people awaited the release of the political prisoners. The title of the matter about this issue once again centralizes the revolutionary actions in the figure of the general: 'Spínola releases political prisoners'.

According to the newspaper, the early morning in Lisbon on April 26 "looked totally calm": trade and banks were open. However, some daily life signs suggested ongoing changes: "signs of the military movement, only tanks parked at strategic points, shredded paper still on the streets, and, most noticeably, the 'uncensored' newspapers, reporting and commenting on everything" (Spínola solta presos políticos, 1974, p. 8).

Some violent incidents indicated the persecution and assault of police officers, especially in front of the DGS headquarters, where groups waited for the policemen who had resisted inside the building "with evident intentions of lynching" (Spínola solta presos políticos, 1974, p. 8). There are several reports, in the analyzed press, of the persecution of "pides". The newly conquered political freedom explodes on the streets. As soon as April 26, according to Jornal do Brasil, thousands of people were participaing in a rally in Rossio Square, "the first rally over almost 50 years, convened by the Democratic Electoral Commission, an organization that joins the parties contrary to the Salazar regime" (Primeiro comício tem bandeiras, 1974, p. 8).

On April 27, the O Estado de S. Paulo highlights in the headline "Spínola releases political prisoners". Similarly to Jornal do Brasil, the cover highlights are the National Salvation Board's first measures in its "program of national pacification, progress and justice" (Spínola liberta presos políticos, 1974, p. 1), the suppression of the outdated structures of Salazarism, and Spínola's "caution" in relation to the "overseas problem" (Um novo país, 1974, p. 1). The O Estado de S. Paulo highlights the international repercussions, opposing "caution" in the USA and "praise" in Moscow (Cautela nos EUA e elogio em Moscou, 1974, p. 1). From Africa, the news are the same as in Jornal do Brasil: apprehension in South Africa and Rhodesia, contentment for the end of the dictatorship, but reassurance that the struggle of the independence movements in Guinea, Angola and Mozambique will continue.

O Estado de S. Paulo's editorial position is expressed on page 3, focusing on the lack of experience and democratic structure in Portugal after 48 years of dictatorship. From 
the Brazilian foreign policy point of view, its understood that the inevitable changes in the relations between Portugal and African territories can bring some relief and can wide the possibility of dialogue between nations, since the signs of mismatching between Brazil and Portugal on the matter was growing bigger, so that a "breakdown could be thought of" (Portugal e a diplomacia, 1974, p. 1).

The topics summarized on the cover are deepened on the inside pages, with emphasis on regaining of democratic freedoms, popular reaction ("The climate is festive in Lisbon") and repercussions in Africa and Europe. News and Quotes from newspapers and sources, mainly from the US, Europe, and Africa, are often identical to those of Jornal do Brasil, indicating the use of sources of news agencies. Coverage differences can be found in the texts of the correspondents. Santana Mota, from Lisbon, highlights the first steps of the Junta de Salvação Nacional and describes details of the shift of power episode from the hands of Marcelo Caetano to General Spínola's, indicating that the latter was not the head of the MFA until he was called to negotiate it with the Prime Minister: "as he did not exercise any leading function in the coup, it was decided to consult the movement leardership, which promptly agreed to hand over the leadership to Spínola" (Mota, 1974, p. 7).

The episode also occupies a news column on page six, under the title of "Caetano's last gesture" (O último gesto de Caetano, 1974, p. 6). The text adds some details to the account of the correspondent Santana Mota, among them, Caetano's assertion that he wanted to pass on the power to him "so that it would not fall into the hands of the rabble" and that the event had been carried out "with exemplary dignity" (O último gesto de Caetano, 1974, p. 6).

From London, the correspondent Hermano Alves analyzes the situation from the point of view of the North Atlantic Treaty Organization: "NATO will be favored". In this reading, the dictatorship in Portugal was seen as a hindrance to this group. "A democratic regime in Portugal paves the way for the country to participate - as a member - in the European Economic Community, and can greatly influence the future of Spain and also Greece" (Alves, 1974, p. 7). It also confirms that, in Africa, the Junta's proposals are considered, both to the left (African independence movements) and to the right (Portuguese communities in these territories), "very liberal" (Alves,1974, p. 7).

Gilles Lapouge, from Paris, says that "in France there is an overall sympathy", an opinion based on the press repercussions in this country, to the left and the right:

From the ultraconservative L'Aurore to the communist L'Humanité, yesterday French newspapers devoted entire pages to Portuguese events. Even L' Aurore, which on some occasions has supported Salazar and Caetano's attitudes, admitted in an article by Roland Faure that the coup was justified. L'Humanité, for its part, issued a rare compliment to the military coup. (Lapouge, 1974, p. 7)

Lapouge worked out an interview with Mário Soares in Paris, in which he stated that "for the Portuguese opposition, there is only one solution: to end the war and recognize 
the personality of the colonies" (Lapouge, 1974, p. 7). Note that Soares does not talk about total independence. The Junta's cautious stance on African issues is supported by press readings, in addition to the analysis of Spínola's past, who was a volunteer in the Spanish Civil War along with Franco, and until recently, a collaborator of Salazar regime:

A few hours after the interview, there were signs in Lisbon that the new government does not intend to initiate contacts with the guerrilla leaders. At least it is the opinion of the journalist Antonio Diez, of L'Express magazine, who declared to the state: "I believe that Spínola will not go as far in liberalization as it was credited. In my opinion, democratic life will be revitalized, but within an authoritarian regime". (Lapouge, 1974, p. 7)

Finally, on April 28, the news about Brazil being the first country to recognize the new regime of Portugal is published, merely through the exchange of communications between the two countries. On O Estado de S. Paulo, the main headline is: "Brazil recognizes the Portuguese Junta". On the cover, new information on popular demonstrations are shown ("After almost 50 years, a day of euphoria in Lisbon") and Spínola's initial concerns ("Spínola fears the misuse of freedom"). The cover includes a photo with the caption "Students dismantle a car of an agent of the former secret police". From the streets of Lisbon, the correspondents Clóvis Rossi and Ewaldo Dantas report rallies and political demonstrations, especially by leftist groups and the hate speech towards PIDE which led to some violent acts, such as the car dismantling and the pursuit of a police officer identified and harassed by the crowd inside a bank, from where he was withdrawn and taken into custody by soldiers. The day started with buildings and buses marked in red spray paint, with the slogan: "The first of May is red". Other slogans were: "People war to colonial war", "Bread, peace, freedom, democracy and national independence". The younger militants were already asking for "Down with Spínola". The journalists also collected testimonies of newly released political prisoners, who reported torture in Portuguese prisons, including deprivation of sleep, contact with the family and beatings. The journalists insisted on asking the prisoners if the police had "drawn blood" from them, which the interviewees denied.

The cover still shows Spínola's manifestations. Before popular euphoria, he declares: "it is natural for people to give vent to their joy. But we should not forget that it is a people that over half a century has not been aware of the use of freedoms". The authoritatively-driven idea that deprivation under dictatorship disabled people for the exercising of freedom and of politics is recurrent, not only among authorities but also in the opinion of newspapers like $O$ Estado de $S$. Paulo, as we have already seen.

It is only on the news published on April 28 that $O$ Estado de S. Paulo attempts to the MFA basic constitution: a youth official movement. Hamilton de Souza, O Estado de S. Paulo's special envoy to Lisbon, writes:

But in the news media, it is said that most of the measures announced by the National Salvation Junta - with the exception of the provinces - do not 
reflect Spinola's thinking. The same sources say that such measures were imposed by the young officers of the Armed Forces. (Souza, 1974, p. 7)

The correspondent also describes the popular adhesion to the unusual Coup, corroborating the view that the April 25 contradicted all the expectations in relation to this type of movement:

Lisbon does not appear to have been the scene of a coup. Except for the vicinity of the quarters and key posts occupied by the troops of General Antonio de Spínola, there is no military movement or indications of police repression. (...) Adhesion to the new government is almost total, and at any moment, supporting releases from different business sectors are radio broadcasted within regular programming. Newspapers, free from censorship, devote almost all space to recent events, always highlighting the release of political prisoners, the normalization of political life and the support manifestations for the Junta. The incredible speed with which people have joined the Armed Forces movement suggests that their anxiety for changing the regime, maintained for 48 years, was firmly rooted in the minds of all Portuguese citizens. (Souza, 1974, p. 7)

O Estado de S. Paulo April 28 editorial reflects on the events in Portugal, revealing, once again, the conservatism and anticommunism of São Paulo daily newspaper. Commenting on the euphoria about the prospects for redemocratization in Portugal, he affirms that, in a "realistic" way, democracy has "morphological constraints" and is achieved through "maturation". Thus, for O Estado de S. Paulo, Portuguese people was not prepared for democracy, since popular education in this form of government was not "a priority of the Salazarist government program" and that "other totalitarian regimes, this time from the left under exogenous influence" could benefit from chaos and disorder.

However, almost fifty years ago, Salazar established his dictatorship to remedy the chaos and disorder caused by the political disintegration. Nearly half a century of dictatorship, in turn, completely alienated people from democratic practices, since popular education on democracy was not one of the priorities of the Salazarist government program, mainly concerned with the need to reorganize, consolidate and discipline the public administration and secure financial bases for production. Thus, there is no denying that democratization should be progressive (...) so that Portuguese people, not prepared and immature to assume cultural and moral responsabilities of self-government, being surprised by the rights derived from freedom, may forget its duties and begin to interpret it and exercise it as libertinism. It is common sense that libertinism leads to chaos and disorder, from which other totalitarian regimes would benefit, this time from the left under exogenous influence. (Os caminhos dos militares portugueses, 1974, p. 3) 
On April 28, Jornal do Brasil's headline is quite similar to that of O Estado de S. Paulo, the first "Portuguese Junta" and the latter "Portugal new government": "Brazil recognizes the new government of Portugal". Similarly to São Paulo newspaper, the emphasis is on Brazil being the first country to recognize the new government and on Spínola's promises of progressive self-determination and independence of Africa territories. The newspaper transcribes the exchange of messages between the Junta and the Ministry of Foreign Affairs. Unlike $O$ Estado de S. Paulo, it emphasizes elements that would be perpetuated as symbols of the event imaginary: the password for the coup was the censored song, Grândola, Vila Morena, by José Afonso. Jornal do Brasil reproduces the lyrics of the song in upper case. Regarding the red carnations, Jornal do Brasil's special envoy, José Silveira, states: "Army and Marine soldiers wearing military campaign uniforms carry light automatic riffles. Many of them carry red carnations in the guns, offered by the population" (Silveira, 1974, p. 3).

In addressing the African issue, Jornal do Brasil highlights the rumors that Portuguese settlers in Mozambique "would be preparing a plan to free the former President Marcelo Caetano from his current confinement on Madeira Island and entrust him with the Mozambican Government, which would declare itself independent of Portugal". The plan is considered 'totally unworkable' by the Junta, not only for Caetano's arrest but also for the Portuguese military adhesion to the Revolution in Mozambique (Colonos de Moçambique querem libertar Caetano, 1974, p. 19).

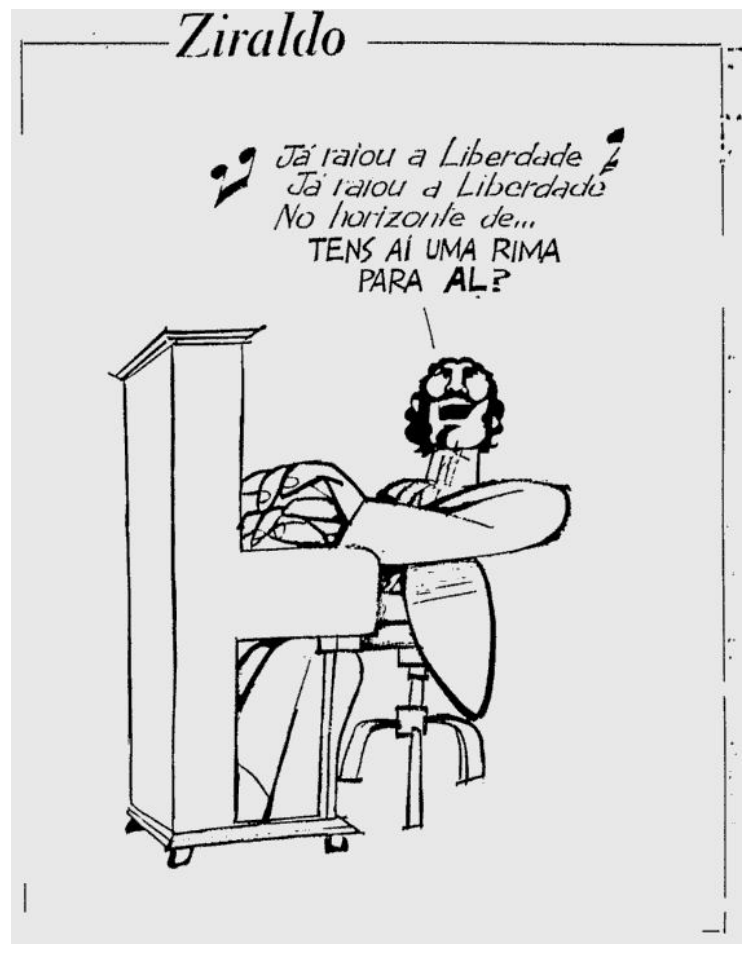

Figure 3: For Ziraldo, freedom has risen in Portugal Source: Jornal do Brasil, April 28, 1974, p. 6 
The narrative on the Revolution of April 25 in our clipping ends in an open way. Where would the military coup d'etat lead Portugal to? Would the military hand over power to civilians? Could democracy establish itself? In Brazil, 10 years of military dictatorship curtails politics and individual freedoms. The offshore winds could bode well. Ziraldo's cartoon (Figure 3), published in Jornal do Brasil, sums up that expectation by invoking the lyrics of the Anthem of Brazil's Independence.

Freedom of expression is one of the most approached points by Brazilian press, with a certain nostalgia. With the popular euphoria and the sudden freedom of expression, Spínola says that the goal is "to create a more responsible press: 'all newspapers should become valid instruments. We cannot allow a climate of irresponsibility" (Spínola teme o uso indevido da liberdade, 1974, p. 1). The same fear regarding the misuse of liberty "is directed to the colonies where Spínola sees there is a confusion between self-determination (stance he defends) and independence, and also to the daily life of Portuguese citizens, who have been deprived of freedom for so long. Ziraldo's cartoon, published in Jornal do Brasil, also focuses on the theme of freedom and suggests that Portuguese people is "forgotten" (Figure 4).

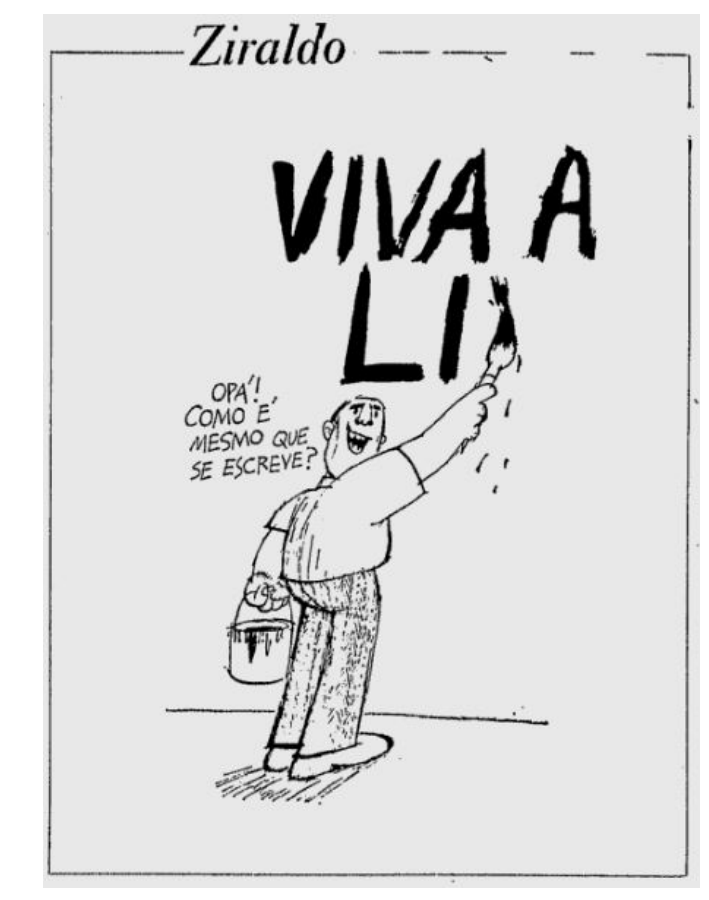

Figure 4: Would the Portuguese people be not familiar with freedom?

Source: Jornal do Brasil, April 27, 1974, p.6

\section{Conclusion}

The recomposition of Brazilian press narrative of April 25 makes clear that the attempt to rewrite freedom has been very challenging. In terms of protagonism, we noticed that the horizontal movement of the young officers caused confusion, and the headlines ended up focusing on the already known figure of Spínola. The Revolution was seen as 
predictable, but its unusual character (popular and peaceful) caused surprise. The theme of freedom has repercussions on domestic politics: even under prior censorship ( $O$ Estado de S. Paulo used to publish Camões sonnets in the spaces cut off by censorship), we saw an authoritarian point of view being defended in the opinion space of the newspaper: Portuguese people was unprepared for democratic life. News coverage, somewhat pasteurized by agencies' texts, becomes colorful in reports from columnists and correspondents. International relations intersperse the coverage, demonstrating that the Portuguese dictatorship pleased a few, and that a new arrangement of forces was in progress in Brazil, in the Portuguese-speaking community. Very little has been reported on the repercussions in African territories, a gap which, as we have pointed out, would greatly contribute to a broader understanding of the meanings of April 25 .

Translation: Beatriz Lahorgue Kunz

\section{REFERENCES}

A queda do regime português (1974, April 26). O Estado de S. Paulo, p. 3.

Alves, H. (1974, April 26). Na Inglaterra, simpatias são mal disfarçadas. O Estado de S. Paulo, p. 9.

Alves, H. (1974, April 27). A NATO sairá favorecida. O Estado de S. Paulo, p. 7.

Brasil aguarda em silêncio (1974, April 26). Jornal do Brasil, p. 4.

Brasil-Portugal (1974, April 26). Jornal do Brasil, p. 6.

Castello Branco, C. (1974, April 26). A libertação de Portugal. Jornal do Brasil, p. 4.

Cautela nos EUA e elogio em Moscou (1974, April 27). O Estado de S. Paulo, p. 1.

Chagas, C. (1974, April 26). Fim do regime apenas traduz a vontade popular. O Estado de S. Paulo, p. 9.

Colonos de Moçambique querem libertar Caetano (1974, April 28). Jornal do Brasil, p. 19.

Como foi o movimento rebelde (1974, April 26). Jornal do Brasil, p. 2.

Fico, C. (2012). Além do golpe: versões e controvérsias sobre 1964 e a Ditadura Militar. Rio de Janeiro: Record.

Frelimo rejeita a proposta (1974, March 28). O Estado de S. Paulo, p. 2.

Geisel faz apelo pela unidade (1974, March 16). O Estado de S. Paulo, p. 1.

Informe Jornal do Brasil (1974, April 26). Jornal do Brasil, p. 10.

Itamaraty não foi surpreendido (1974, April 26). O Estado de S. Paulo, p. 1.

Junta dissolve polícia e Partido salazaristas (1974, April 27).Jornal do Brasil, p. 8.

Lacerda, C. (1974, April 9). Portugal acha a solução. O Estado de S. Paulo, p. 5.

Lapouge, G. (1974, April 26). Por momentos, a França esquece a campanha eleitoral. O Estado de S. Paulo, p. 9. 
Lapouge, G. (1974, April 28). Na França, há simpatia geral. O Estado de S. Paulo, p. 7.

Lisboa sufoca revolta mas crise se agrava (1974, March 17). O Estado de S. Paulo, p. 1.

Livro se esgota em duas cidades (1974, April 27). Jornal do Brasil, p. 9.

Mário Soares oferece apoio (1974, April 26). O Estado de S. Paulo, p. 9.

Martinho, F. C. P. (2007). Léguas a nos separar: o que levou o regime militar brasileiro a apoiar um movimento de esquerda como a Revolução dos Cravos em Portugal? Revista de História da Biblioteca Nacional, 42, 63-68.

Martins, M. L. (1992). A dona de casa e a caravela transtlântica. Estudo sócio-antropológico sobre o imaginário salazarista. Cadernos do Noroeste, 5, 191-204. Retrieved from http://repositorium.sdum. uminho.pt/handle/1822/25357

Martins, M. L. (2014). Os mitos de origem no salazarismo - o passado como se fora presente. In M. M. Baptista, J. E. Franco \& B. Cieszynska (Eds.), Europa das nacionalidades: imaginários, identidades e metamorfoses políticas (pp. 185-191). Coimbra: Grácio Editor.

Martins, M. L. (2017). O olho de Deus no discurso salazarista. Porto: Afrontamento.

Militares acabam salazarismo e prometem eleição (1974, April 26). Jornal do Brasil, p. 2.

Mota, S. (1974, March 16). Em Portugal, a situação agora é menos confusa. O Estado de S. Paulo, p. 2.

Mota, S. (1974, April 26). Às 4 da tarde, o final de uma era. O Estado de S. Paulo, p. 1.

Mota, S. (1974, April 27). Junta inicia sua missão. O Estado de S. Paulo, p. 7.

Motta, L. G. (2005). A análise pragmática da narrativa jornalística. In Anais do XXVIII Congresso Brasileiro de Ciências da Comunicação (pp. 1-15). Rio de Janeiro: UERJ. Retrieved from http://www.portcom.intercom. org.br/pdfs/105768052842738740828590501726523142462.pdf

Mundo aguarda o desfecho da crise (1974, April 26). O Estado de S. Paulo, p. 9.

Nora, P. (1979). O retorno do fato. In J. Le Goff, \& P. Nora, História: novos problemas (pp. 179-193). Rio de Janeiro: Francisco Alves.

Nora, P. (1983). Monster events. Discourse, 5, 5-20.

O último gesto de Caetano (1974, April 27). O Estado de S. Paulo, p. 6.

Os caminhos dos militares portugueses (1974, April 28). O Estado de S. Paulo, p. 3.

Os feitos de Spínola o destacam como líder (1974, March 17). O Estado de S. Paulo, p. 14.

Para Lacerda, era previsível o que aconteceu (1974, April 26). O Estado de S. Paulo, p. 9.

Patrício rejeita alteração (1974, March 17). O Estado de S. Paulo, p. 1.

Portugal à margem do mundo (1974, April 26). Jornal do Brasil, p. 4.

Portugal e a diplomacia (1974, April 27). O Estado de S. Paulo, p. 1.

Primeiro comício tem bandeiras (1974, April 26). Jornal do Brasil, p. 8. 
Rebeldes tentam evitar choque armado em Lisboa (1974, April 25). Jornal do Brasil, p. 14 [ $3^{\circ}$ clichê].

Recrudesce em Portugal a crise político-militar (1974, March 16). O Estado de S. Paulo, p.1.

Rosas, F. (2013). Salazar e o poder - a arte de saber durar. Lisboa: Tinta-da-China.

Silva, J. M. da. (2006). As tecnologias do imaginário. Porto Alegre: Sulina.

Silveira, J. (1974, April 28). Novos hóspedes nas prisões. Jornal do Brasil, p. 3.

Sodré, M. (2009). A narração do fato: notas para uma teoria do acontecimento. Petrópolis: Vozes.

Souza, H. de (1974, April 28). Oficialidade jovem parece controlar a Junta. O Estado de S. Paulo, p. 7.

Spínola liberta presos políticos (1974, April 27). O Estado de S. Paulo, p. 1.

Spínola solta presos políticos (1974, April 27). Jornal do Brasil, p. 8.

Spínola teme o uso indevido da liberdade (1974, April 28). O Estado de S. Paulo, p. 19.

Tropa rebelada marcha em direção à Lisboa (1974, April 25). Jornal do Brasil, p. 14 [2 clichê].

Um novo país (1974, April 27). O Estado de S. Paulo, p. 1.

Vieira, J. \& Monico, R. (2014). Nas bocas do mundo: o 25 de Abril e o PREC na imprensa internacional. Lisboa: Tinta-da-China.

\section{BIOGRAPHICAL NOTE}

Camila Garcia Kieling - PhD in Social Communication at the Pontifical Catholic University of the State of Rio Grande do Sul - PUCRS (Porto Alegre, Brazil). Associate professor at the School of Communications, Arts and Design in the same institution.

Email: camila.kieling@gmail.com

Aderess: Avenida Otto Niemeyer, 1025 apto. 707B - 91910-001 - Porto Alegre, RS, Brasil.

* Submitted: 15.05.2018

* Accepted: 21.06.2018 